\title{
Black locust (Robinia pseudoacacia L.) ecophysiological and morphological adaptations to drought and their consequence on biomass production and water-use efficiency
}

Dario Mantovani ${ }^{1,3^{*}}$, Maik Veste $^{1,2}$ and Dirk Freese ${ }^{1}$

\begin{abstract}
Background: Successful plantation efforts growing Robinia pseudoacacia L. (black locust) in the drier regions of Hungary and East Germany (Brandenburg), have demonstrated the potential of black locust as an alternative tree species for short-rotation biomass energy plantations.

Methods: The response of black locust to water limitation was investigated in a lysimeter experiment. Plants were grown under three different soil moisture regimes, with values set at 35\%,70\%, and 100\% of the soil water availability, namely WA35, WA70, and WA100. Their morphological adaptation and productivity response to water constraint were assessed together with their water-use efficiency. Furthermore, the ecophysiological adaptation at the leaf level was assessed in terms of net photosynthesis and leaf transpiration.

Results: During the growing season, plants in the WA35, WA70, and WA100 treatments transpired 239, 386, and 589 litres of water respectively. The plants subjected to the WA35 and WA70 treatments developed smaller leaves compared with the plants subjected to the WA100 treatment (66\% and $36 \%$ respectively), which contributed to the total leaf area reduction from $8.03 \mathrm{~m}^{2}$ (WA100) to $3.25 \mathrm{~m}^{2}$ (WA35). The total above-ground biomass produced in the WA35 $(646 \mathrm{~g})$ and WA70 $(675 \mathrm{~g})$ treatments reached only $46 \%$ and $48 \%$ of the biomass yield obtained in the WA100 (1415 g). The water-use efficiency across all treatments was $2.31 \mathrm{~g} \mathrm{~L}^{-1}$. At vapour pressure deficit (VPD) values $<1.4 \mathrm{kPa}$ trees growing under the WA35 soil moisture regime showed a stomatal down-regulation of transpiration to $5.3 \mathrm{mmol} \mathrm{m} \mathrm{m}^{-2} \mathrm{~s}^{-1}$, whereas the trees growing under the WA100 regime did not regulate their stomatal conductance and transpiration was $11.7 \mathrm{mmol} \mathrm{m}^{-2} \mathrm{~s}^{-1}$, even at VPD values $>2 \mathrm{kPa}$.

Conclusions: Black locust plants can adapt to prolonged drought conditions by reducing water loss through both reduced transpiration and leaf size. However, under well-watered conditions it does not regulate its transpiration, and therefore it cannot be considered a water-saving tree species.
\end{abstract}

Keywords: Lysimeter; Water availability; Water use efficiency; Biomass production; Drought; Transpiration

\footnotetext{
* Correspondence: mantdar2@gmail.com

'Brandenburg University of Technology Cottbus-Senftenberg, Chair of Soil

Protection and Recultivation, Konrad-Wachsmann-Allee 6, 03046 Cottbus, Germany

${ }^{3}$ CRA - OLI- Consiglio per la Ricerca e la sperimentazione in Agricoltura, centro di ricerca per l'olivicoltura e l'industria olearia, via Nursina 2, 06049 Spoleto, (PG), Italy

Full list of author information is available at the end of the article
} 


\section{Background}

The production of biomass as a renewable resource for bioenergy has become increasingly important in Germany during recent decades. This had led to the promotion of an environmentally sustainable economy and increasing reliance on carbon-neutral renewable energy along with policies for reducing fossil fuel use and $\mathrm{CO}_{2}$ emissions. However, the traditional use of woody biomass as firewood is changing to a versatile source for larger biomass power plants. Short-rotation forestry (SRF) has great potential to contribute to such increased demands for growing woody biomass (Mitchell et al. 1999; Weih 2004; Grünewald et al. 2007). The planting of fast-growing trees for bioenergy can be an alternative land-use option on marginal land, where economically effective crop production is limited (Sinclair et al. 2005). Furthermore, interest in the ecological benefit of SRF for the restoration of ecosystem function (Lockwell et al. 2012) has increased considerably for recultivated post-mining areas (Šourková et al. 2005; Quinkenstein et al. 2009; Keskin and Makineci 2009). Water limitation and drought conditions in spring and summer are quite common in many regions, including in Brandenburg (Eastern Germany), where this experiment was carried out. Regional climate models for the next few decades are predicting changes to seasonal precipitation distribution and a summer rainfall decrease of 10-30\% (Cubasch and Kadow 2011; Schaller 2011). Moreover, the intensification of extreme events will expand also across Europe over the next few decades, affecting ecosystem functioning (Jentsch and Beierkuhnlein 2008), tree distribution, growth rate, and productivity (Hickler et al. 2012). Successful plantation efforts growing Robinia pseudoacacia L. (black locust) in the drier regions of Hungary and East Germany (Brandenburg) (Rédei 2002; Rédei et al. 2008; Grünewald et al. 2009), with an annual mean precipitation lower than $600 \mathrm{~mm} \mathrm{yr}^{-1}$, have demonstrated the potential of black locust as an alternative tree species for short-rotation biomass energy plantations. As a pioneer species, black locust is fast-growing and able to fix nitrogen from the atmosphere in considerable amounts (Xiao-rong et al. 2010). For example, Veste et al. (2013) estimated an annual nitrogen fixation by black locust of $47.9-84.9 \mathrm{~kg} \mathrm{~N} \mathrm{ha}^{-1} \mathrm{yr}^{-1}$ on reclaimed postmining land in Lusatia (East Germany). Furthermore, this tree species is known to be relatively drought tolerant compared with other temperate, deciduous tree species (Mantovani et al. 2014, Veste and Kriebitzsch 2013). However, the native range of black locust in North America, humid to sub-humid climate, with a required annual precipitation of 1020 to $1830 \mathrm{~mm}$ (Schütt 2010). Until now, most studies on black locust have focused mainly on ecophysiological adaptations of this species to drought conditions (Veste and Kriebitzsch 2013; Liu et al.
2008; Zhang et al. 2012), emphasising its high ecophysiological plasticity. However, at the whole-plant level, biomass production sensitivity to water limitation is more related to plant growth performance and cell formation, rather than to carbon uptake and photosynthesis (Körner 2013). Consequently, a deeper understanding of the intertwined processes at both levels is needed in order to identify correlations between growth performance, biomass production, and transpiration of the whole tree under different soil water availability regimes and atmospheric boundary conditions. To study the consequences of water shortage, the number of variables involved in the soil-plant-atmosphere system was reduced by performing an investigation in lysimeters, under controlled environmental conditions. The aim of this study was to evaluate the impact of ecophysiological and morphological adaptation to water limitation on the biomass production and water use efficiency of black locust. Specifically, variation among water treatments at the whole-plant level was assessed in terms of a) transpiration, b) growth rate, c) leaf traits, and d) primary production. The results of this study provide detailed information on the physiology and biomass production capacity of black locust across a range of soil water conditions, which is essential for guiding future management strategies for short-rotation forestry.

\section{Methods}

\section{Plant material}

Two-year-old saplings were collected from a short-rotation plantation in the post-mining area of Welzow-Süd, Brandenburg, Germany (N 51 $36^{\prime} 14^{\prime \prime}$, E $\left.14^{\circ} 19^{\prime} 51^{\prime \prime}\right)$. The climate at the collection site is transitional between oceanic and continental. The mean annual rainfall is $556 \mathrm{~mm}$ and the mean annual temperature is $9.3^{\circ} \mathrm{C}$ (Meteorological Station Cottbus 1951-2003). Trees were selected in order to have a comparable trunk diameter (approximately $16 \mathrm{~mm}$ ) and height (approximately $280 \mathrm{~mm}$ ). To reduce variation in crown structure, clones presenting only three primary branches were chosen and these were cut back at $100 \mathrm{~mm}$ from the trunk before they were transplanted. The nine selected trees were planted directly in $15 \mathrm{~L}$ pots and over-wintered under a lighttransmissive shelter to avoid frost damage. In March 2011, the young plants were transplanted into wick lysimeters (three trees per lysimeter; Mantovani et al. 2013; Ben-Gal and Shani 2002) and fertilised with $1045 \mathrm{~mL}$ of Hoagland standard solution (Hoagland and Arnon 1950) and $3.18 \mathrm{~g}$ of potassium dihydrogen phosphate $\left(\mathrm{KH}_{2} \mathrm{PO}_{4}\right)$. The trees were well-watered in the lysimeters during the establishment phase until the start of the experiment in June 2011.

\section{Lysimeter system}

The nine wicked lysimeters used for water balance and growth performance evaluations were constructed as 
follows: polyethylene drums $\left(1968 \mathrm{~cm}^{3}, 25 \mathrm{~cm}\right.$ radius $\times 50$ $\mathrm{cm}$ depth) were filled with sandy loam soil at bulk density of $1.3 \mathrm{~kg} \mathrm{~m}^{-3}$, low in carbon $(1.33 \%)$ and nitrogen $(0.08 \%)$ Bulk density was estimated by using the thermo-gravimetric method (Jury and Horton 2004) while the total $\mathrm{C}$ and total $\mathrm{N}$ were estimated with the dry combustion method by using an elemental analyzer (Elemental Vario EL, LT Scientific, Inc. Nevada, USA). Water was supplied from an automatic drip-irrigation system, installed at the soil-atmosphere interface, only when the soil moisture reached values lower than the predefined values. Uncontrolled water input was avoided by installing the system under a light-transmissive roof and the evaporation was minimised by covering the soil with two separate geotextile layers. To control the irrigation amount and frequency, the soil moisture was measured at $20 \mathrm{~cm}$ depth with a Frequency Domain Reflectometry (FDR) probe (SM-200, Frequency Domain Reflectometry, Soil Moisture Sensor Delta-T Devices, Cambridge, UK). A supplementary FDR probe was installed at $40 \mathrm{~cm}$ depth to monitor the soil moisture gradient along the profile. To measure the soil matric potential, two gypsum tensiometers (SIS, UMS, München, Germany) were installed at 20 and $40 \mathrm{~cm}$ depth. Solar radiation and wind speed were recorded using a photosynthetically active radiation (PAR) sensor (QS2, Delta-T Devices, Cambridge, UK) and a switching anemometer (A100R, 119 Vector Instruments, Rhyl, UK) respectively) All measurements were logged at hourly intervals. The data were stored on data loggers (GP1, Delta-T Devices, Cambridge, UK) and transferred using a Global System for Mobile Communications (GSM) wireless data transmission system to an internet platform (WEBVis, Umweltanalystische Produkte $\mathrm{GmbH}$, Cottbus, Germany). The daily mean vapour pressure deficit (VPD) was calculated from the daily mean temperature and relative humidity, measured from 9:00 to 18:00. The variation in water storage requirements for the weekly water budget calculation was obtained by measuring the soil moisture at four depths (10, 20,30, and $40 \mathrm{~cm})$ with a portable FDR profile probe $(\mathrm{PR} 2 / 4 \mathrm{w}-02$, Delta-T Devices, Cambridge, UK) on a weekly basis. Water use for a single plant during the growing season was evaluated from the experimental water balance. Water use efficiency (WUE) was calculated at harvest by the ratio between the total above-ground dry biomass (defined and determined below) produced from each tree and its cumulative water use. The economic water-use efficiency was calculated taking only the economically relevant woody biomass into account, since only the only the wood is harvested.

\section{Water regime treatments}

Plants were assigned to one of three water treatments, with three replicates each, namely low-water amount (i.e. drought stressed) (WA35), intermediate water amount (WA70) and maximum water amount (WA100). All plants were kept from 1 June to 8 November 2011 under constant soil moisture values of $7 \%, 14 \%$, and $20 \%$ respectively (Table 1). The predefined soil moisture values were selected, taking the hydraulic property of the lysimeters and the physiological characteristics of the plants into account. The lower soil moisture limit of $7 \%$ corresponds to the minimum value above wilting point, while the soil moisture value of $20 \%$ matched the hydrostatic state of the lysimeter (Table 1). Hence in relative terms, the WA100 treatment was considered to be the maximum (100\%) possible soil water availability, while WA70 and WA35 correspond to $70 \%$ and $35 \%$ of the water availability respectively.

\section{Biomass and leaf area}

Three parameters were evaluated monthly throughout the growing season, from 1 June 2011 (at which point the plants had already fully developed leaves) to 8 October 2011 (when the leaf abscission occurred), as a proxy for growth rate. The diameter of the trunk and all secondary branches were measured periodically with a pair of callipers, while the lengths of the secondary branches were measured using a graduated pole. For the determination of the annual total production, all above-ground biomass (except the trunks and primary branches) was harvested at the end of the growing season on 8 November and oven-dried at $65^{\circ} \mathrm{C}$ until a steady weight was reached. The volume of the trunk and primary branches, were estimated at the beginning and the end of the experiment by measuring the length and the mean diameter. The difference in volume recorded, multiplied by the specific weight of the black locust dry wood $\left(0.76 \mathrm{~g} \mathrm{~cm}^{-2}\right)$ was used to estimate the gravimetric increment $(\mathrm{g})$ of the trunk and the primary branches

Table 1 Description of the soil water availability conditions of the treatments

\begin{tabular}{|c|c|c|c|c|c|c|}
\hline Treatment & $\begin{array}{l}\text { Number of } \\
\text { trees } \\
\text { (n) }\end{array}$ & $\begin{array}{l}\text { Number of } \\
\text { lysimeters } \\
\text { (n) }\end{array}$ & $\begin{array}{l}\text { Relative soil water } \\
\text { availability } \\
\text { (\%) }\end{array}$ & $\begin{array}{l}\text { Soil water } \\
\text { content } \\
(\text { Vol-\%) }\end{array}$ & $\begin{array}{l}\text { Soil matric } \\
\text { potential } \\
\text { (pF) }\end{array}$ & Limits \\
\hline WA35 & 3 & 3 & 35 & 7 & $<-3.5$ & Wilting limit \\
\hline WA70 & 3 & 3 & 70 & 14 & 2.5 & Intermediate \\
\hline WA100 & 3 & 3 & 100 & 20 & $>-2$ & Hydrostatic state \\
\hline
\end{tabular}


occurred during the growing season. A polyethylene funnel-shaped net was installed around the entire crown of each tree. All fallen odd pinnate leaves (leaflet and petiole) (Figure 1) were collected daily from this net from the beginning of the plant senescence (15 September) until the end of the experiment (8 November 2011). For the calculation of the mean leaf area (individual leaf) of each tree, 10 fully developed leaves were collected from each tree during the growing season and their areas were evaluated by using a digital image processing technique (GNU Image Manipulation Program 2.6, Berkeley, California, and UTHSCSA ImageTool, San Antonio, Texas). The same leaves were oven-dried at $65^{\circ} \mathrm{C}$ and their weight related to their area, in order to obtain the area/weight index. The total leaf area for each tree was calculated by multiplying the area/weight index by the weight of its total dry leaves.

\section{Net photosynthesis and transpiration}

The gas exchange of fully expanded leaves was measured in situ employing a CMS400 minicuvette system (Heinz Walz GmbH, Effeltrich, Germany) (Midgley et al. 1997; Veste and Herppich 1995). Gas exchange measurements were carried out with ambient $\mathrm{CO}_{2}$ concentrations and the $\mathrm{H}_{2} \mathrm{O}$ and $\mathrm{CO}_{2}$ concentrations were determined with an infra-red gas analyser (BINOS 100-4P, Rosemount, Hanau, Germany). Each portion of leaf (couple of leaflets) was placed in the minicuvette for 5-6 minutes until a constant $\mathrm{H}_{2} \mathrm{O}$ signal was reached. Transpiration and $\mathrm{CO}_{2}$ exchange were calculated according to Koch et al. (1971). Leaf conductance for water vapour $\left(\mathrm{g}_{\mathrm{H} 2 \mathrm{O}}\right)$ was calculated using the method of von Caemmerer and Farquhar (1981), with software DIAGAS 2.0 (Heinz Walz GmbH, Effeltrich, Germany), and all fluxes were calculated in relation to the projected leaf area. Each portion of leaf was scanned and its area measured by using the same digital image processing technique described in the previous section. During the measurements, the air temperature and relative humidity in the cuvette were

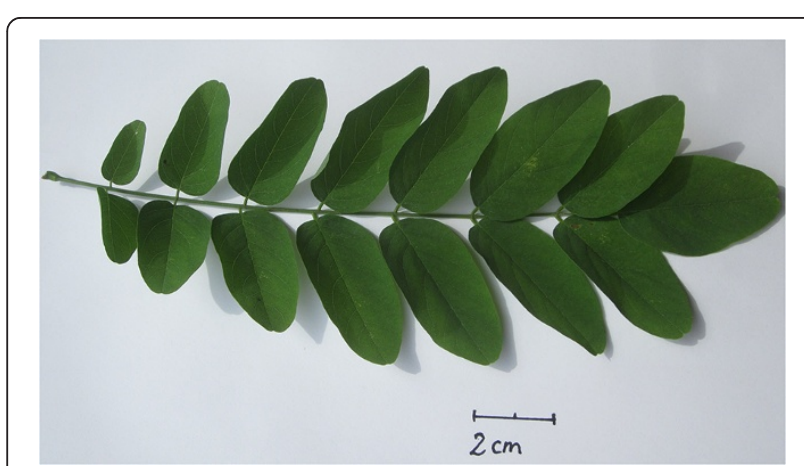

Figure 1 Detail of black locust odd pinnate leaf, leaflet in row, one at the tip. kept constant and corresponded closely to the actual ambient VPD. Three days with different temperature and humidity conditions were selected: I) $20^{\circ} \mathrm{C}$, VPD $0.7 \mathrm{kPa}$, II) $25^{\circ} \mathrm{C}, 1.4 \mathrm{kPa}$, and III) $32^{\circ} \mathrm{C}, 2.3 \mathrm{kPa}$, that represented typical summer days in July and August, and the minicuvette was adjusted to these actual temperature and humidity conditions. The illumination was set to a constant value of $1100 \mu \mathrm{mol} \mathrm{m} \mathrm{m}^{-2} \mathrm{~s}^{-1}$ using an external halogen lamp to ensure the light-saturation of the photosynthesis.

\section{Statistical analysis}

This work involved investigation of plants at two levels: I) plant level for transpiration and growth performance and II) the leaf level for transpiration and net photosynthesis. As a result, the statistical analysis required the use of different analytic tools. Before performing the statistical tests, the data were tested for normality by the Shapiro-Wilk test. Regression analysis was used to correlate cumulative water use with soil water availability, and water use with biomass production. The non-parametric Spearman's rho $(\alpha=0.01)$ test was used to correlate transpiration rate, growth rate and VPD at the individual-leaf level and at the whole-plant level. A non-parametric analysis using the Mann-Whitney $U$-Test $(\alpha=0.05)$ was performed to compare the treatments in terms of cumulative transpiration, total leaf area, trunk diameter, biomass production and WUE. For branch diameter and length increase, a parametric ANOVA, Post-Hoc analysis Tukey HSD $(\alpha=0.05)$, was performed and a parametric Robust Test, Post-Hoc Games-Howell $(\alpha=0.05)$, was used for the leaf traits. All the analyses were executed using IBM SPSS software, version 21 (SPSS Inc. Chicago, IL).

\section{Results}

\section{Environmental data}

Details of the air temperature, relative humidity, and VPD of the course of the experiment are shown in Figure 2. Air temperature and VPD declined towards the end of the experiment while periods of high relative humidity increased.

\section{Tree transpiration}

The cumulative transpiration mean increased from $239 \pm 44 \mathrm{~L}$ (mean \pm standard deviation) (WA35) to $386 \pm 7$ L (WA70) and $589 \pm 149 \mathrm{~L}$ (WA100) (Figure 3). Differences among treatments were significant and the relationship between the relative water availability and the cumulative transpiration reduction was linear $\left(r^{2}=0.99\right)$. For all treatments, the highest water consumption occurred during the late summer months (August and September), with $61 \%, 60 \%$, and $68 \%$ of the cumulative transpiration for WA35, WA70, and WA100 respectively. That period (August and September) was characterised by 


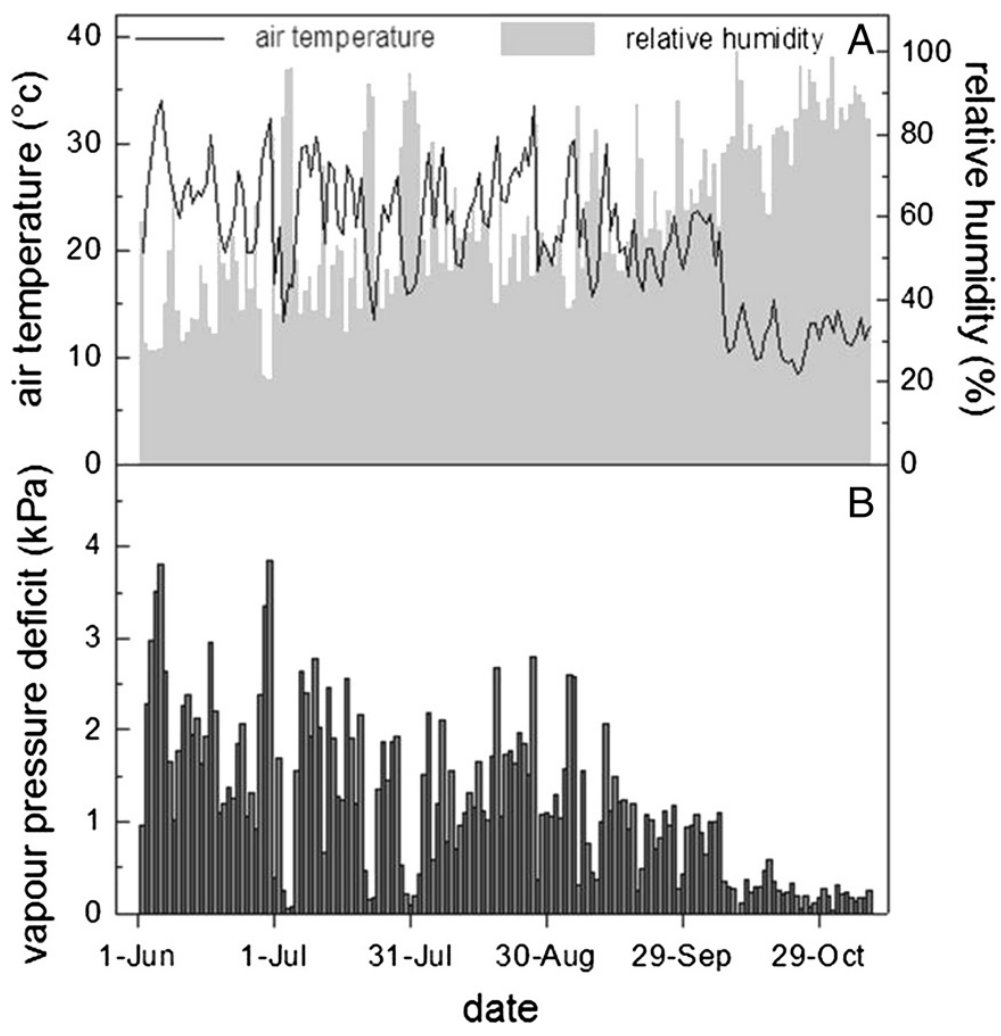

Figure 2 Mean values of the daily climatic condition of A) air temperature and relative humidity, B) vapour pressure deficit, measured during the growing season from 1 June to 8 November 2011.

days with relatively high daily mean air temperatures and VPD values of $>1.3 \mathrm{kPa}$ (Figure 2). During October, the transpiration rate remained static across the soil moisture treatments due to lower air temperatures and VPD values. Plant responses to the VPD differed significantly among treatments (Figure 4). The mean weekly transpiration and the mean weekly VPD were correlated linearly for the WA100 treatment $\left(\mathrm{Y}=38.58 * \mathrm{X}, r^{2}=0.90\right)$, with

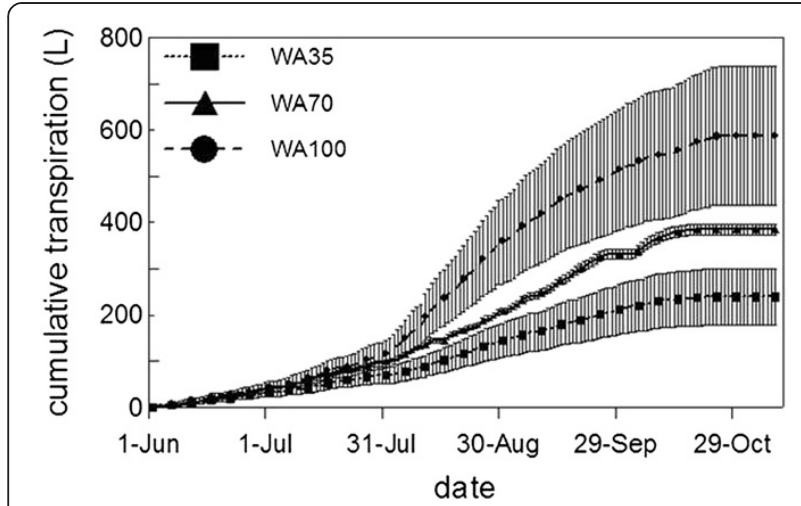

Figure 3 Mean cumulative transpiration of the different treatments, measured during the growing season from 1 June to 8 November 2011. significant coefficient of correlation $\left(r_{s}=0.779\right)$. There was no significant correlation for either WA70 or WA35. In these cases, the relationships are better described by asymptotic functions.

\section{Plant growth rate}

Although similar trends were found for each of the three growth-rate variables (trunk diameter and branch

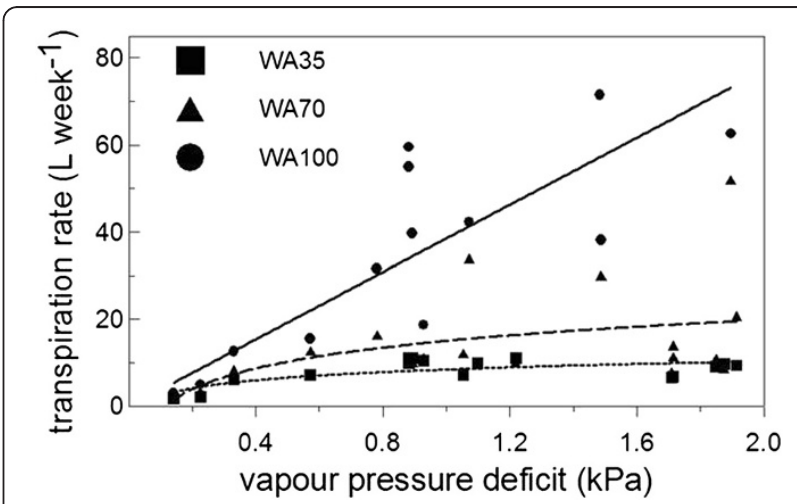

Figure 4 Mean weekly transpiration of the different treatments in relation to the mean weekly vapour pressure deficit, measured during the growing season from 1 June to 8 November 2011. 
diameter and length) tested (Figure 5), most of the differences between the treatments were not significant Table 2 . The relationship between growth variables evaluated and cumulative transpiration was significant (Figure 6). The highest Spearman's rho coefficient of correlation found was for the diameter increment of secondary branches (0.993), followed by the maximum length of secondary branches (0.979) and the trunk diametric increase (0.965).

\section{Biomass production}

A decrease in primary production followed the reduction in growth rate. The total above-ground biomass and wood produced by the trees from the WA35 treatment reached only $46 \%$ and $45 \%$ of the values seen with the plants growing under the WA100 regime respectively, and the difference for both variables was significant (Figure 7). Also, the WA70 biomass production was less than half $(48 \%)$ of that for WA100 and this difference was also significant. No statistical differences in either total above-ground biomass or wood production were

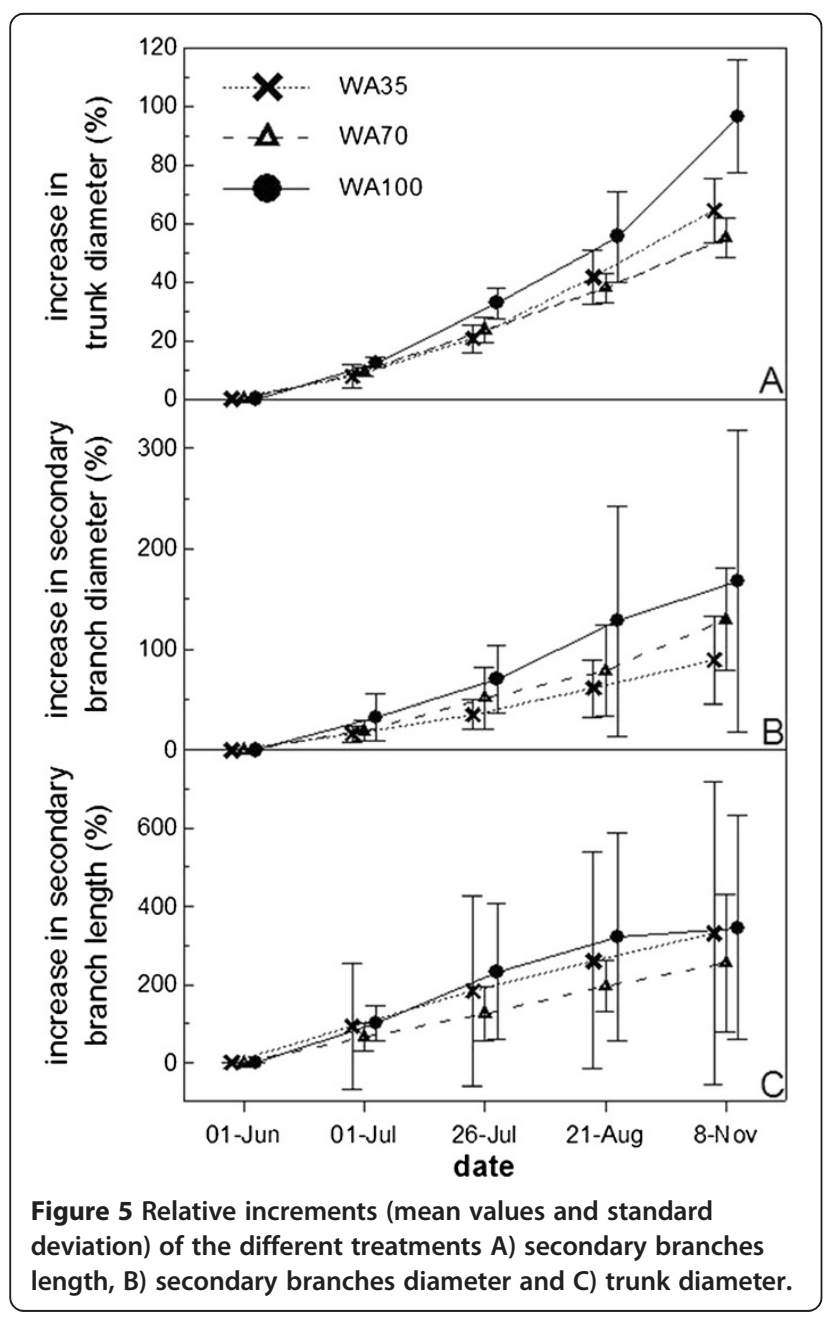

detected among the treatments in terms of WUE. From the relationship between the above-ground biomass produced and the transpired water, linear yield-transpiration models were constructed (Figure 8). The WUE was $2.31 \mathrm{~g} \mathrm{~L} \mathrm{~L}^{-1}\left(\mathrm{r}^{2}=0.98\right)$ when total biomass production was considered and $1.63 \mathrm{~g} \mathrm{~L}^{-1}\left(r^{2}=0.97\right)$ when only wood production was taken into account.

\section{Leaf size}

Black locust plants responded to water constraints, not only by reducing transpirational water loss (Figure 4) but also by producing smaller leaves (Figure 9). The mean individual leaf area of WA100 plants was significantly higher (56\% greater) than that for the plants subjected to the WA35 (Figure 9A). The mean total leaf area of the drought stressed trees (WA35, $3.25 \mathrm{~m}^{2}$ ) was significantly reduced by $60 \%$ compared with WA100 trees $\left(8.03 \mathrm{~m}^{2}\right)$, and by $42 \%$ for WA70 trees $\left(4.65 \mathrm{~m}^{2}\right)$.

\section{Leaf gas exchange}

Leaf transpiration and $\mathrm{CO}_{2}$ exchange rate were under the control of the microclimatic conditions in the minicuvette, only during the flux measurements. At a temperature of $20^{\circ} \mathrm{C}(\mathrm{VPD}=0.7 \mathrm{kPa})$, no significant differences between the treatments were recorded (Figure 10A) either for transpiration or $\mathrm{CO}_{2}$ flux. When the air temperature was raised to $25^{\circ} \mathrm{C}(\mathrm{VPD}=1.4 \mathrm{kPa})$, the transpiration rate of the WA35 trees was significantly lower, reaching only $31 \%$ and $37 \%$, of the WA100 $(\alpha=0.046)$ and WA70 trees $(\alpha=0.044)$ respectively (Figure $10 \mathrm{C})$. At these same microclimatic conditions, the $\mathrm{CO}_{2}$ exchange rate of the WA35 trees was also significantly lower, being only $19 \%$ and $20 \%$ of the WA100 $(\alpha=0.042)$ and WA70 trees $(\alpha=0.042)$ respectively (Figure 9D). When the air temperature rose to $32^{\circ} \mathrm{C}(\mathrm{VPD}=2.3 \mathrm{kPa})$ (Figure 10E), transpiration of the WA35trees was $48 \%$ and $45 \%$, lower than the W100 $(\alpha=0.038)$ and W70 trees $(\alpha=0.038)$ respectively (Figure 10E). However, the $\mathrm{CO}_{2}$ exchange rate did not differ significantly among the treatments (Figure 10F). The drought-stressed plants (WA35) always maintained low transpiration level $\left(2.8-5.6 \mathrm{mmol} \mathrm{m}^{-2} \mathrm{~s}^{-1}\right)$, irrespective of the microclimatic conditions (Figure 11). The mean transpiration rate of WA70 and WA100 trees increased from 1.9 to $12.1 \mathrm{mmol} \mathrm{m}^{-2} \mathrm{~s}^{-1}$ and from 2.2 to $14.7 \mathrm{mmol} \mathrm{m}^{-2} \mathrm{~s}^{-1}$ respectively, as the VPD increased. During the day with the highest VPD $\left(32^{\circ} \mathrm{C}, 2.3 \mathrm{kPa}\right)$, the relationship between water availability and transpiration was linear $\left(r^{2}=0.86\right)$. The coefficient of determination decreased $\left(r^{2}=0.71\right)$ during the day with intermediate VPD values $\left(25^{\circ} \mathrm{C}, 1.4 \mathrm{kPa}\right)$, and there was no linearity $\left(r^{2}=0.10\right)$ for the day with the lowest VPD $\left(20^{\circ} \mathrm{C}, 0.7\right.$ VPD). The Spearman's rho value was only significant for the plants from the WA100 treatment $\left(r_{s}=0.913\right)$. Changes in the transpiration response to differing VPD at 
Table 2 Relative trunk diameter and secondary branches diameter and length increases, recorded from the beginning of the experiment (1 June 2011) to the end (8 November 2011)

\begin{tabular}{|c|c|c|c|c|c|c|}
\hline Treatment & $\begin{array}{l}\text { Trunk diameter } \\
\text { increase } 1 \%)\end{array}$ & Std & $\begin{array}{l}\text { Secondary branches } \\
\text { diameter increase }{ }^{2}(\%)\end{array}$ & Std & $\begin{array}{l}\text { Secondary branches } \\
\text { length increase }{ }^{2}(\%)\end{array}$ & Std \\
\hline WA35 & $64.30 a$ & 10.78 & $89.43 a$ & 43.26 & $331.06 a$ & 388.48 \\
\hline WA70 & $55.04 a$ & 6.579 & $130.00 \mathrm{a}$ & 51.29 & 255.70a & 175.41 \\
\hline WA100 & $96.37 b$ & 19.33 & $168.55 a$ & 149.79 & $345.56 a$ & 285.81 \\
\hline
\end{tabular}

${ }^{1}$ Parametric analysis: ANOVA, Post-Hoc analysis Tukey HSD $(p<0.05)$.

${ }^{2}$ Non parametric analysis: Mann-Whitney U-Test $(p<0.05)$.

*Different letterers indicate significant difference between the values.

the individual-leaf level (Figure 12) resembled the pattern observed at the whole-plant level (Figure 4). At the individual-leaf level, the relationship was linear for both the WA100 $\left(r^{2}=0.99\right)$ and WA70 $\left(r^{2}=0.99\right)$ trees, but the coefficient of determination was low for the WA35 trees $\left(r^{2}=0.67\right)$. Results of Spearman's rho analysis showed that only the correlation between WA35 plants and VPD was significant $\left(r_{s}=0.821\right)$.

Increases in leaf transpiration for the WA70 and WA100 trees were not accompanied by an increase of the net $\mathrm{CO}_{2}$ exchange. The $\mathrm{CO}_{2}$ flux remained constant at all values of transpiration tested. Instead, there was linearity between the transpiration rate and the $\mathrm{CO}_{2}$ exchange rate for the trees from the WA35 treatment $\left(\mathrm{r}^{2}=0.92\right)$, where the Spearman's rho value was significant $\left(r_{s}=0.857\right)$. At the leaf level, the WUE of the WA35 plants was more than $50 \%$ lower, compared with the plants from the two treatments with higher soil water availability (WA70 and WA100). However, this difference was statistically not significant due to the large within-treatment variation.

\section{Discussion}

Various studies conducted on the drylands of China (Hu et al. 2001) and under the extreme edaphic conditions

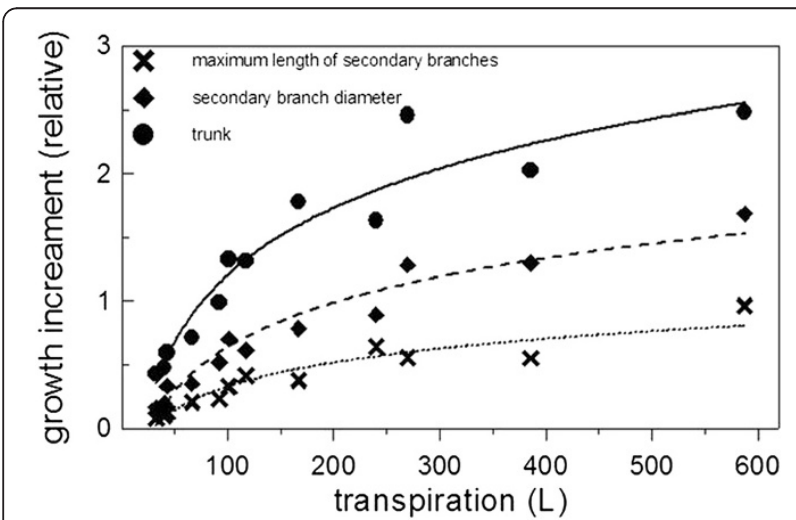

Figure 6 Relation between the mean cumulative transpiration and the mean relative increments of the different treatments: maximum length and diameter of secondary branches, measured four times during the growing season from 1 June to 8 November 2011. of post-mining sites in Bulgaria (Filcheva et al. 2000) and Eastern Germany (Böhm et al. 2011) have emphasised the growth potential of black locust on marginal land. The results presented here show how black locust responds to water limitation by reducing transpiration at both the individual-leaf level and at the whole-plant level, in relation to the climatic conditions. The differences in transpiration rates among the treatments were most pronounced during mid-summer and less significant in autumn, when the VPD was very low and leaves had senesced. The linear relationship between transpiration and biomass (wood and total above ground) production found in the current study is well supported at the whole-plant level by the homogeneity of the WUE among the treatments, i.e. $2.31 \pm 0.46 \mathrm{~g} \mathrm{~L}^{-1}$ when total above-ground production was considered and $1.63 \pm 0.39 \mathrm{~g} \mathrm{~L}^{-1}$ when only wood production was taken into account.

However, lower WUE values (0.32 to $0.71 \mathrm{~g} \mathrm{~L}^{-1}$ ) were obtained for black locust in a field experiment under semi-arid conditions on the Loess Plateau in Inner Mongolia ( $\mathrm{Hu}$ et al. 2001). In another field study, Raper et al. (1992) reported extremely low WUE values of 0.03 to $0.09 \mathrm{~g} \mathrm{~L}^{-1}$ in Georgia, USA. Higher WUE values have been found in other common tree species used for short-rotation For example Salix

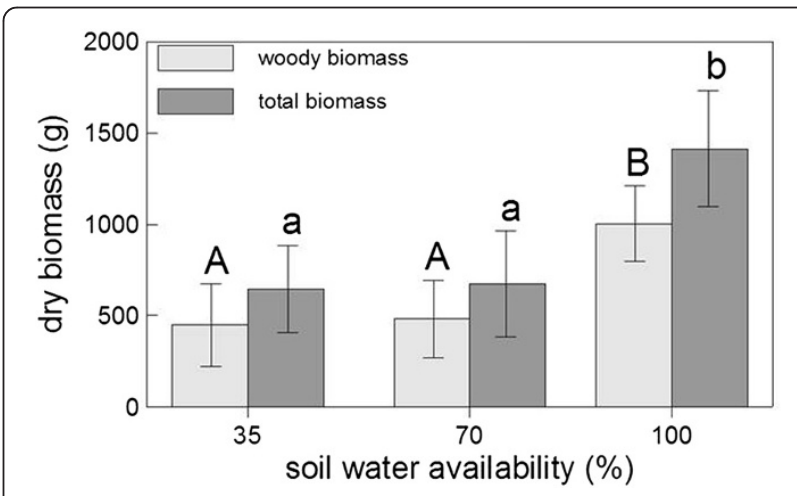

Figure 7 Mean and standard deviation of total wood and leaf weight for the different treatments in relation to relative soil water availability. Non parametric analysis Mann-Whitney U-Test. *Different letters indicate significant difference $(p<0.05)$. 


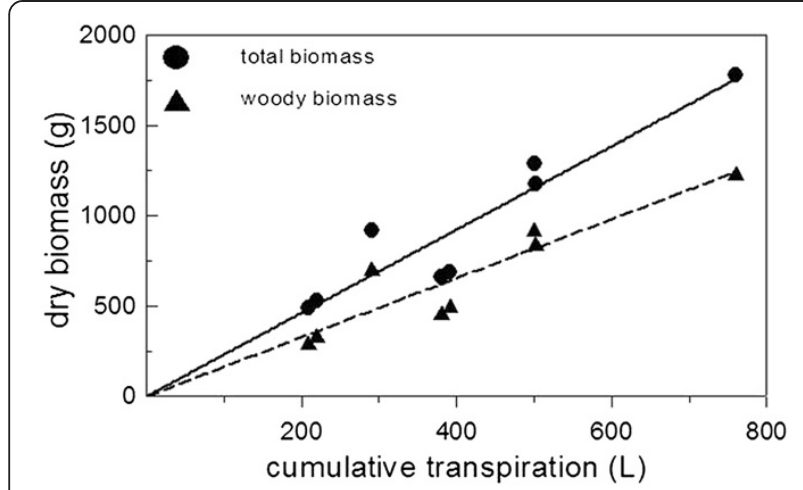

Figure 8 Dry total above-ground biomass $\left(Y=2.31 * X, r^{2}=0.98\right)$ and woody biomass $\left(Y=1.64 * X, r^{2}=0.97\right)$ produced from different treatments in relation to the cumulative transpiration during the growing season from 1 June to 8 November 2011.

viminalis L. growing in northern Europe had WUE values in the range 4.1-5.5 $\mathrm{g} \mathrm{L}^{-1}$ (Lindroth et al. 1994) while WUE values at different soil moisture regimes for Populus simonii Carrière, growing in the northwest region of the Loess Plateau (a highland area in north-central China) had ranged from 4.76 to $6.09 \mathrm{~g} \mathrm{~L}^{-1}$ (Liang et al. 2006). All these results are in line with the typical values estimated for a range of tree species growing in temperate

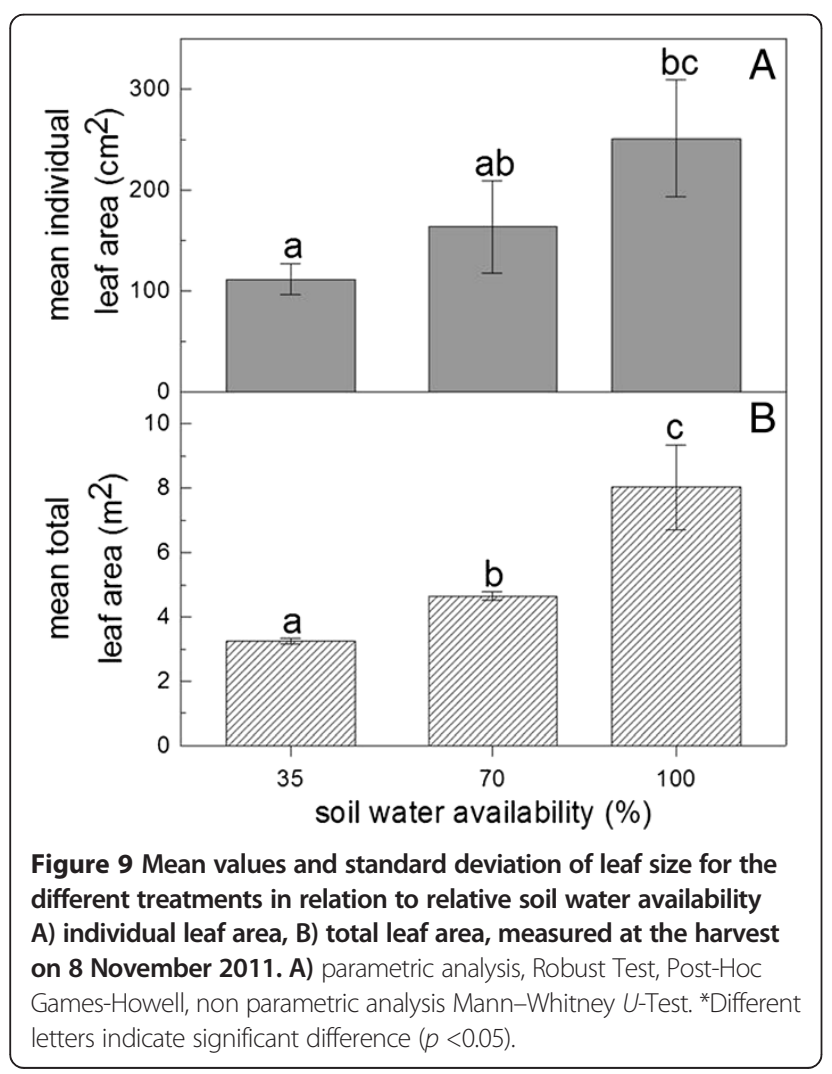

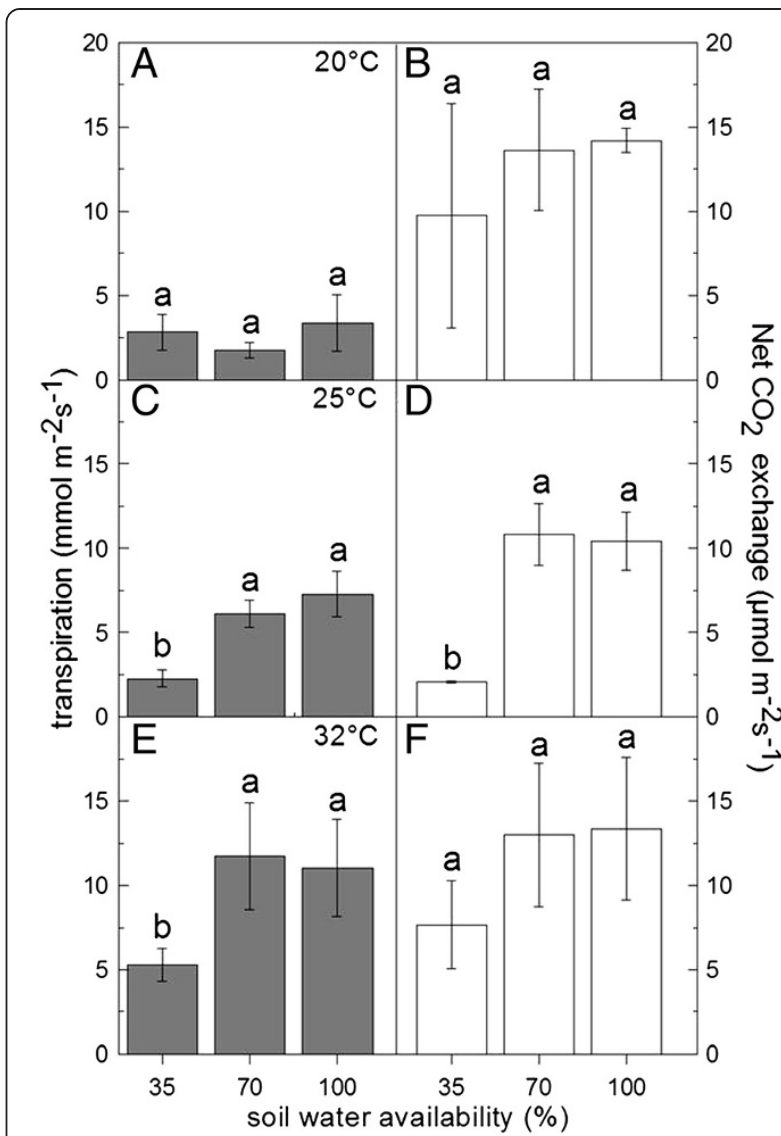

Figure 10 Transpiration and net $\mathrm{CO}_{2}$ exchange rate (mean and standard deviation) in relation to soil water availability, measured at leaf level during days with different climatic conditions: $A$ ) and B) $20^{\circ} \mathrm{C}, \mathrm{VPD} 0.7 \mathrm{kPa}, \mathrm{C}$ ) and D) $\left.25^{\circ} \mathrm{C}, \mathrm{VPD} 1.4 \mathrm{kPa}, \mathrm{E}\right)$ and F) $32^{\circ} \mathrm{C}$, VPD $2.3 \mathrm{kPa}$. Non parametric analysis Mann-Whitney U-Test. *Different letters indicate significant difference $(p<0.05)$.

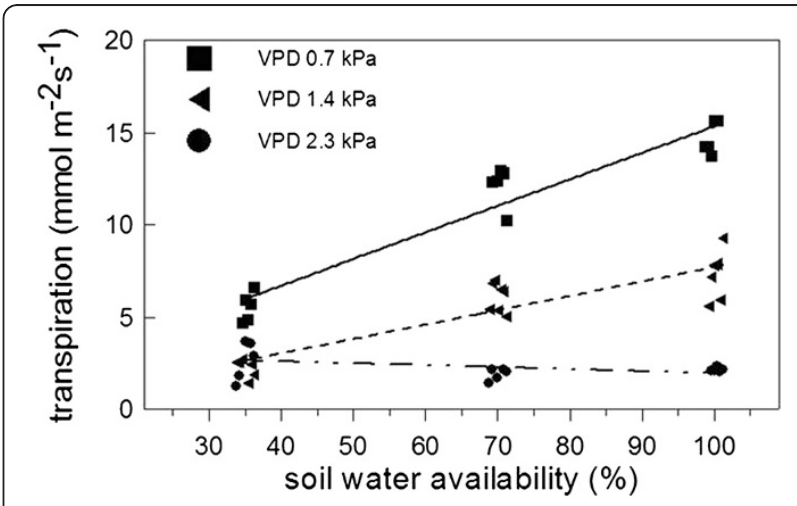

Figure 11 Leaf transpiration from individual leaf, rate during days with different climatic condition (air temperatures and VPD) in relation to the relative soil water availability. 


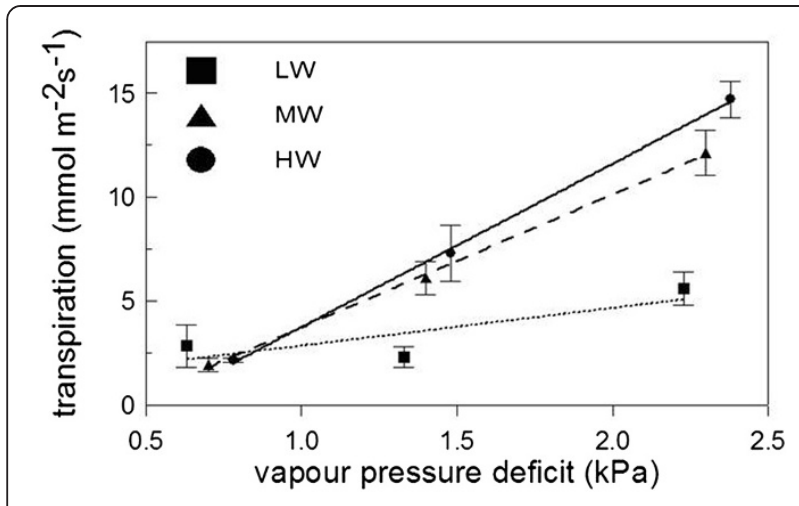

Figure 12 Mean leaf transpiration rate for the different treatments, measured at the individual leaf level under different climatic conditions (air temperatures and VPD).

climate zones where the water-use efficiency range lies between 1.42 and $6.66 \mathrm{~g} \mathrm{~L}^{-1}$ (Penka 1985). Comparable results were also found for well-watered Populus przewalskii Maximowicz and Populus cathayana Rehder plants with 4.08 and $4.6 \mathrm{~g} \mathrm{~L}^{-1}$ respectively, in an indoor experiment (Yin et al. 2005). Transpiration of black locust at both the individual-leaf level and at the whole-plant level was not limited by the stomata when soil water supply was optimal under the climatic conditions the current investigation. However, a limited soil water supply under the same climatic conditions resulted in a reduced transpiration rate, in order to minimise water loss. Similar behaviour has been observed for other broad-leaved trees (Gollan et al. 1985; Sperry 2000). That explains why towards the end of the growing season (October) the weekly transpiration mean was comparable between the treatments, even though the transpiring surfaces of the trees was significantly different. This confirms earlier findings about the leaf transpiration under well-watered conditions, where the leaf transpiration increased concomitantly with the VPD, while the net $\mathrm{CO}_{2}$ was nearly constant (Veste and Kriebitzsch 2013). As reported from other studies (Tipton and White 1995; Rashidi et al. 2011; Schurr et al. 2000; Niu et al. 2008), adaptation to water limitation also implies morphological changes. Among them, reduction in the dimensions of individual leaves (and consequently total leaf area) due to a water shortage are important morphological adaptations in order to control water loss (Xu et al. 2009, Veste and Kriebitzsch 2013). The slow but constant growth of drought-stressed plants (WA35) in the current study indicates an adaptation to minimise water loss in a water limited environment. The drought-related decline in the area of individual leaves may be a consequence of a low turgor pressure impairing cell growth and expansion (Jaleel et al. 2009). Further limited transpiration had severe repercussions on the growth rate, as was shown here by reduced growth of the trunk and secondary branches. The recorded reduction in primary production at the wholeplant level was explained at the individual-leaf level by the linear relation between the transpiration and the $\mathrm{CO}_{2}$ exchange rate shown by the drought stressed plants (WA35). The well-watered plants (WA100) fluxes $\left(\mathrm{CO}_{2}\right.$ and $\left.\mathrm{H}_{2} \mathrm{O}\right)$ could only be limited by metabolic requirements of the plants and the atmospheric concentrations, rather than the constraints imposed by stomatal regulation, as already reported in literature (Körner 2013; Muller et al. 2011). Consequently, the identification of the combined effect of soil water availability and atmospheric evaporative demand as driving factors for the water use efficiency variability is crucial to understanding the response of the plants to different environmental conditions in terms of production.

\section{Conclusion}

The plants showed a high plasticity to water shortage, since drought stress at values close to the wilting point did not affect the plants' functionality although it did affect their growth. Black locust has lower WUE than other species grown in short-rotation coppice species so is certainly not a low water-use tree species. Thus, growing black locust in a plantation setting may affect ground-water recharge and the local water budget. However, its ability to grow under adverse edaphic conditions plus other traits not studied here (such as high wood density and rot resistance) makes it a suitable species for marginal lands. Growth performance and morphological adaptations were more sensitive than the photosynthesis across the range of soil water availabilities tested, and hence growth is limited by factors other than photosynthetic $\mathrm{C}$ gain.

\section{Competing interests}

The authors declare that they have no competing interests.

\section{Authors' contributions}

All authors have contributed substantially to this manuscript. DM was conducted the lysimeter experiment, involved in planning, data analyses and manuscript writing. MV involved in the ecophysiological measurements, planning, data analysis, and manuscript writing. DF was involved in the experimental planning, supervision of all the experimental work and in writing the manuscript. All authors read and approved the final manuscript.

\section{Author details}

${ }^{1}$ Brandenburg University of Technology Cottbus-Senftenberg, Chair of Soil Protection and Recultivation, Konrad-Wachsmann-Allee 6, 03046 Cottbus, Germany. ${ }^{2}$ CEBra - Centre for Energy Technology Brandenburg e.V, Friedlieb-Runge-Str. 3, 03046 Cottbus, Germany. ${ }^{3}$ CRA - OLI- Consiglio per la Ricerca e la sperimentazione in Agricoltura, centro di ricerca per l'olivicoltura e I'industria olearia, via Nursina 2, 06049 Spoleto, (PG), Italy.

Received: 8 February 2014 Accepted: 11 November 2014

Published online: 05 December 2014 


\section{References}

Ben-Gal, A, \& Shani, U. (2002). A highly conductive drainage extension to control the lower boundary condition of lysimeters. Plant and Soil, 239, 9-17.

Böhm, C, Quinkenstein, A, \& Freese, D. (2011). Yield prediction of young black locust (Robinia pseudoacacia L.) plantations for woody biomass production using allometric relations. Annals of Forest Research, 54(2), 215-227.

Cubasch, U, \& Kadow, C. (2011). Global change and aspects of regional climate change in Berlin-Brandenburg region. Die Erde, 142(1-2), 3-20.

Filcheva, E, Noustorova, M, Gentcheva-Kostadinova, S, \& Haigh, MJ. (2000). Organic accumulation and microbial action in surface coal-mining spoils, Pernik, Bulgaria. Ecological Engineering, 15, 1-15.

Gollan, T, Turner, NC, \& Schulze, ED. (1985). The responses of stomata and leaf gas exchange to vapour pressure deficits and soil water content. III. In the sclerophyllous woody species Nerium oleander. Oecologia, 65, 356-362.

Grünewald, H, Brandt, BKV, Schneider, BU, Bens, O, Kendzia, G, \& Hüttl, RF. (2007) Agroforestry systems for the production of woody biomass for energy transformation purposes. Ecological Engineering, 29, 319-328.

Grünewald, H, Böhm, C, Quinkenstein, A, Grundmann, P, Eberts, J, \& Wühlisch, G. (2009). Robinia pseudoacacia L. A lesser known tree species for biomass production. BioEnergy Research, 2, 123-133.

Hickler, T, Bolte, A, Hartard, B, Beierkuhnlein, C, Blaschke, M, Blick, T, Brüggemann, W, Dorow, WHO, Fritze, MM, Gregor, T, Ibisch, P, Kölling, C, Kühm, I, Musche, M, Pompe, S, Petercord, R, Schweiger, O, Seidling, W, Trautmann, S, Walenspuhl, T, Walentowski, H, \& Wellbrock, N. (2012). Folgen des Klimawandels für die Biodiversität in Wald und Forst. In V Mosbrugger, GP Brasseur, M Schaller, \& B Stribrny (Eds.), Klimawandel und Biodiversität: Folgen für Deutschland (pp. 164-221). Darmstadt: Wissenschaftliche Buchgesellschaft.

Hoagland, DR, \& Arnon, DI. (1950). The Water-Culture Method for Growing Plants Without Soil. California Agricultural Experiment Station, Circular No. 347. University of California, Berkeley, CA, USA.

Hu, ZH, Wang, ZG, Gao, HX, \& Wang, LJ. (2001). Research on water changes and water use efficiency in Loess gully region in Western Shanxi Province. Journal of Shanxi Agricultural University, 21(3), 248-251.

Jaleel, CA, Manivannan, P, Wahid, A, Farooq, M, Al-Juburi, HJ, Somasundaram, R, \& Panneerselvam, R. (2009). A review of whole-plant water use studies in trees. Tree Physiology, 18, 499-512.

Jentsch, A, \& Beierkuhnlein, C. (2008). Research frontiers in climate change: effects of extreme meteorological events on ecosystems. Comptes Rendus Geoscience, 340, 621-628.

Jury, WA, \& Horton, R. (2004). Soil Physics. John Wiley \& Sons. Hoboken, N.J.

Keskin, T, \& Makineci, E. (2009). Some soil properties on coal mine spoils reclaimed with black locust (Robinia pseudoacacia L.) and umbrella pine (Pinus pinea L.) in Agacli-Istanbul. Environment Monitoring and Assessment, 159, 407-414.

Koch, W, Lange, OL, \& Schulze, ED. (1971). Ecophysiological investigations on wild and cultivated plants in the Negev desert, I. Methods: A mobile laboratory for measuring carbon dioxide and water vapour exchange. Oecologia, 8, 269-309.

Körner, MLC. (2013). Growth controls photosynthesis - mostly. Nova Acta Leopoldina NF, 114, 273-283.

Liang, ZS, Yang, J, Shao, HB, \& Hana, RL. (2006). Investigation on water consumption characteristics and water use efficiency of poplar under soil water deficits on the Loess Plateau. Colloids and Surfaces B: Biointerfaces, $53,23-28$.

Lindroth, A, Verwijst, T, \& Halldin, S. (1994). Water-use efficiency of willow: variation with season, humidity and biomass allocation. Journal of Hydrology, $156,1-19$.

Liu, LM, Qi, H, Luo, XL, \& Zhang, X. (2008). Coordination effect between vapor water loss through plant stomata and liquid water supply in soil-plant-atmosphere continuum (SPAC): a review. Ying Yong Sheng Tai Xue Bao, 19(9), 2067-2073.

Lockwell, J, Guidi, W, \& Labrecque, M. (2012). Soil carbon sequestration potential of willows in short-rotation coppice established on abandoned farm lands. Plant and Soil, 360, 299-318.

Mantovani, D, Veste, M, \& Freese, D. (2013). Evaluation of fast growing tree transpiration under different soil moisture regimes using wicked lysimeters. iForest - Journal of Biogeosciences and Forestry, 6, 190-200.

Mantovani, D, Veste, M, Freese, D (2014). Effects of drought frequency on growth performance and transpiration of young black locust (Robinia pseudoacacia L.). International Journal of Forestry Research, 2014, 11 pages, Article ID 821891. http://dx.doi.org/10.1155/2014/821891.
Midgley, G, Veste, M, von Willert, DJ, Davis, GW, Steinberg, M, \& Powrie, LW. (1997). Comparative field performance of three different gas exchange systems. Bothalia, 27(1), 83-89.

Mitchell, CP, Stevens, EA, \& Watters, MP. (1999). Short-rotation forestry - operations, productivity and costs based on experience gained in the UK. Forest Ecology and Management, 121, 123-136.

Muller, B, Pantin, F, Genard, M, Turc, O, Freixes, S, Piques, M, \& Gibon, Y. (2011). Water deficits uncouple growth from photosynthesis, increase $C$ content, and modify the relationships between $C$ and growth in sink organs. Journal of Experimental Botany, 62, 1715-1729.

Niu, G, Rodriguez, DS, \& Mackay, W. (2008). Growth and physiological responses to drought stress in four oleander clones. Journal of American Society Horticultural Science, 133(2), 188-196.

Penka, M. (1985). Transpiration and Consumption of Water by Plants. Prague: Academia.

Quinkenstein, A, Wöllecke, J, Böhm, C, Grünewald, H, Freese, D, Schneider, BU, \& Hüttl, RF. (2009). Ecological benefits of the alley cropping agroforestry system in sensitive regions of Europe. Environmental Science \& Policy, 12, 1112-1121.

Raper, SM, Steinbeck, K, Moss, IS, \& Whitehead, D. (1992). Water use efficiency and transpiration of Robinia, Liquidambar, and Platanus sprouts in the south eastern USA. Forest Ecology and Management, 51(4), 259-268.

Rashidi, F, Jalili, A, Kafaki, SB, Sageb-Talebi, K, \& Hodgson, J. (2011). Anatomical response of leaves of Black Locust (Robinia pseudoacacia L.) to urban pollutant gases and climatic factors. Trees, 26(2), 363-375.

Rédei, K. (2002). Management of black locust (Robinia pseudoacacia L.) stands in Hungary. Journal of Forestry Research, 13(4), 260-264.

Rédei, K, Osváth-Bujtás, Z, \& Veperdi, I. (2008). Black locust (Robinia pseudoacacia L.) Improvement in Hungary: a Review. Acta Silvatica et Lignaria Hungarica, $4,127-132$.

Schaller, E. (2011). Simulation des Gegenwärtigen und Zukünftigen Regioalklimas von Brandenburg. In RF Hüttl, R Emmermann, S Germer, M Naumann, \& O Bens (Eds.), Globaler Wandel und Regionale Entwicklung: Anpassungsstrategien in der Region Berlin-Brandenburg (pp. 37-42). Heidelberg, Berlin, New York: Springer.

Schurr, U, Heckenberger, U, Herdel, K, Walter, A, \& Feil, R. (2000). Leaf development in Ricinus communis during drought stress: dynamics of growth processes, of cellular structure and of sink-sources transition. Journal of Experimental Botany, 51(350), 1515-1529.

Schütt, P. (2010). Robinia Pseudoacacia. In A Roloff, U Lang, H Weisgerber, \& B Stimm (Eds.), (Hrsg.) Bäume Nordamerikas: von Alligator-Wachholder bis Zuckerahorn (pp. 216-230). Wiley-VCH, Weinheim.

Sinclair, TR, Holdbrook, NM, \& Zwieniecki, MA. (2005). Daily transpiration rates of woody species on drying soil. Tree Physiology, 25(11), 1469-1472.

Šourková, M, Frouz, J, \& Šantrǔčková, H. (2005). Accumulation of carbon, nitrogen and phosphorus during soil formation on alder spoil heaps after brown-coal mining, near Sokolov, Czech Republic. Geoderma, 124(1), 203-214.

Sperry, JS. (2000). Hydraulic constraints on plant gas exchange. Agricultural and Forest Meteorology, 104(1), 13-23.

Tipton, JL, \& White, M. (1995). Differences in leaf cuticle structure and efficacy among eastern redbud and Mexican redbud phenotypes. Journal of American Society Horticultural Science, 120(1), 59-64.

Veste, M, \& Herppich, W. (1995). Diurnal and seasonal fluctuations in the atmospheric $\mathrm{CO}_{2}$ concentration and their influence on the photosynthesis of Populus tremula. Photosynthetica, 31(3), 371-378.

Veste, M, \& Kriebitzsch, WU. (2013). Einfluss von Trockenstress auf Photosynthese, Transpiration und Wachstum junger Robinien (Robinia pseudoacacia L.). Forstarchiv, 84, 35-42.

Veste, M, Böhm, C, Quinkenstein, A, \& Freese, D. (2013). Biologische Stickstoff-Fixierung der Robinie. AFZ-Der Wald, 2, 40-42.

Von Caemmerer, SV, \& Farquhar, GD. (1981). Some relationships between the biochemistry of photosynthesis and the gas exchange of leaves. Planta, 153(4), 376-387.

Weih, M. (2004). Intensive short-rotation forestry in boreal climates: present and future perspectives. Canadian Journal of Forest Research, 34(7), 1369-1378.

Xiao-rong, W, Ming-an, S, Xing-chang, Z, Hong-bo, S. (2010). Landform affects on profile distribution of soil properties in black locust (Robinia pseudoacacia L.) land in loessial gully region of the Chinese Loess Plateau and its implications for vegetation restoration. African Journal of Biotechnology, 8, 13.

Xu, F, Guo, W, Xu, W, Wei, Y, \& Wang, R. (2009). Leaf morphology correlates with water and light availability: What consequences for simple and compound leaves? Progress in Natural Science, 19(1789), 1798. 
Yin, C, Wang, X, Duana, B, Luob, J, \& Li, C. (2005). Early growth, dry matter allocation and water use efficiency of two sympatric Populus species as affected by water stress. Environmental and Experimental Botany, 53, 315-322.

Zhang, Y, Equiza, M, Zheng, Q, \& Tyree, M. (2012). Factors controlling plasticity of leaf morphology of Robinia pseudoacacia L. II: the impact of water stress on leaf morphology of seedlings grown in a controlled environment chamber. Annals of Forest Science, 69, 39-47.

doi:10.1186/s40490-014-0029-0

Cite this article as: Mantovani et al:: Black locust (Robinia pseudoacacia

L.) ecophysiological and morphological adaptations to drought and their consequence on biomass production and water-use efficiency. New Zealand Journal of Forestry Science 2014 44:29.

\section{Submit your manuscript to a SpringerOpen ${ }^{\circ}$} journal and benefit from:

- Convenient online submission

- Rigorous peer review

- Immediate publication on acceptance

- Open access: articles freely available online

- High visibility within the field

- Retaining the copyright to your article 